\title{
Pengaruh Strategi Product, Price, Promotion terhadap Keputusan Nasabah Melakukan Pembiayaan pada PT BPRS Puduarta Insani Medan
}

\author{
Nur Ainun*, \\ Fakultas Soshum dan Pendidikan, Universitas Haji Sumatera Utara, Indonesia \\ 름ainunnst65@gmail.com \\ Sandhi Fialy Harahap ${ }^{2}$, \\ Fakultas Soshum dan Pendidikan, Universitas Haji Sumatera Utara, Indonesia \\ sandhifialy94@gmail.com
}

\section{Abdi Sugiarto}

Fakultas Ekonomi dan Bisnis, Universitas Tcut Nyak Dhien

mimoabdi2@gmail.com

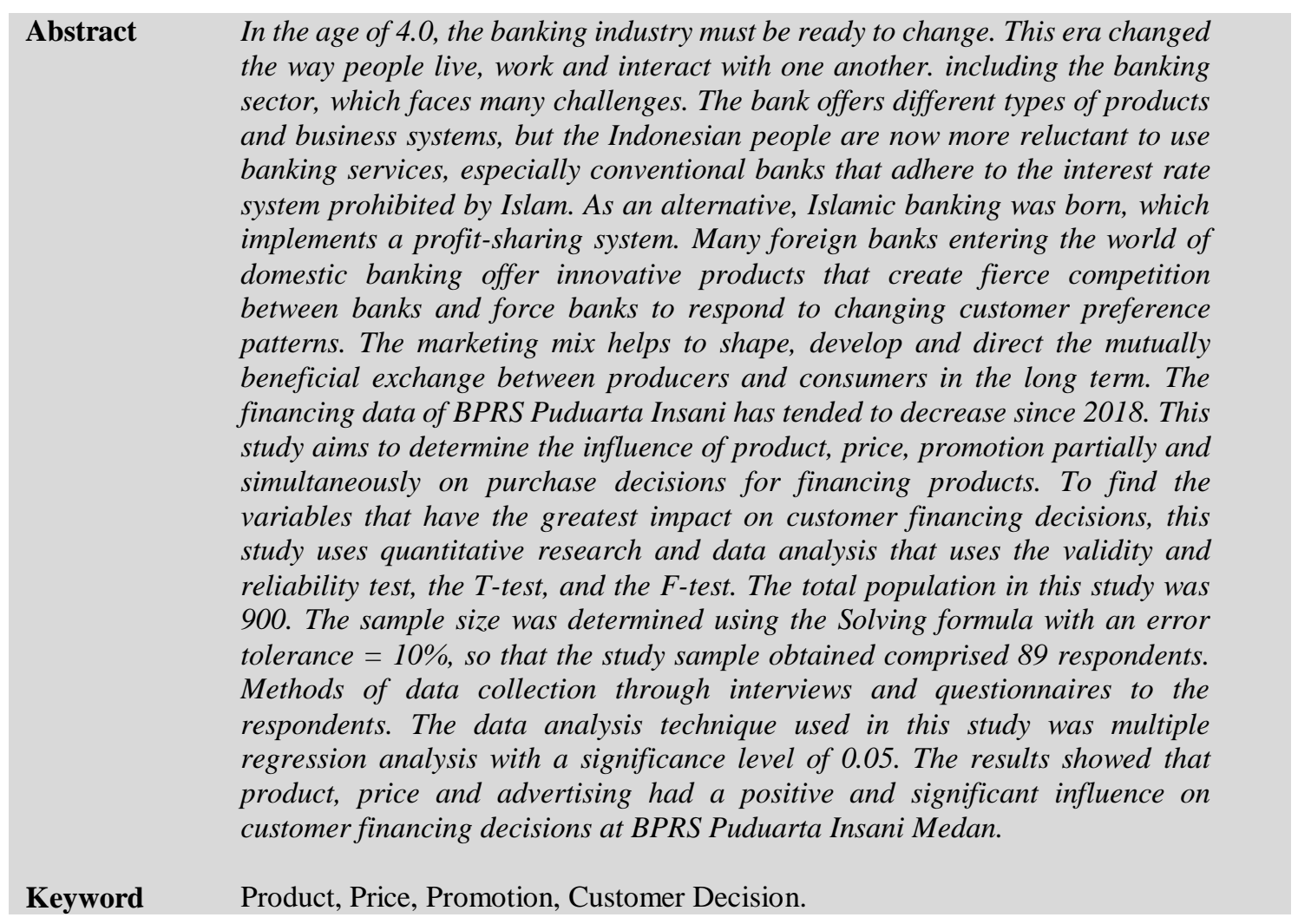

\section{PENDAHULUAN}

Perkembangan perbankan syariah di Indonesia telah menjadi tolak ukur keberhasilan eksistensi ekonomi syariah. Bank mualamat merupakan salah satu Bank Syariah pertama yang menjadi pioner bagi Bank lainnya. Hal ini dibuktikan dengan krisis moneter pada tahun 1998 telah menenggelamkan bank-bank konvensional sehingga banyak yang di likuidasi akibat kegagalan sistem bunganya, sementara perbankan yang menerapkan sistem syariah mampu bertahan eksis sampai saat ini. Bank Pembiayaan Rakyat Syariah diatur dalam Undang-Undang No 10 Tahun 1998. Di Indonesia, regulasi mengenai bank syariah tertuang dalam UU No.21 Tahun 2008 perbankan syariah. Bank syariah adalah bank yang yang menurut jenisnya terdiri atas Bank Umum Syariah, Unit Usaha Syariah dan Bank Pembiayaan Rakyat Syariah. BPRS Puduarta Insani salah satu 
perbankan syariah yang menjadi pilihan masyarakat dalam mengembangkan usaha mikro, kecil dan menengah serta memberikan pembiayaan kepada masyarakat kecil menengah ke bawah.

"Prinsip Syariah adalah aturan perjanjian berdasarkan hukum Islam antara Bank dengan pihak lain untuk menyimpan dana atau pembiayaan kegiatan badan usaha, atau kegiatan lainnya yang sesuai dengan syariah, antara lain pembiayaan berdasarkan prinsip bagi hasil (Mudharabah), pembiayaan dengan prinsip penyertaan modal (Musyarakah), prinsip jual beli dengan memperoleh keuntungan (Murabahah) atau pembiayaan barang modal berdasarkan prinsip sewa murni tanpa pilihan pemindahan kepemilikan atas barang yang disewa dari pihak bank oleh pihak lain (Ijarah wa iqtina)."

Pertumbuhan sektor jasa yang begitu cepat diantaranya dipicu oleh perubahan demografis, sosial, perekonomian, politik dan lain sebagainya. Hal tersebut tentunya akan menjadikan orang semakin hati-hati dalam memilih sektor jasa yang akan dijadikan sebagai mitranya. Untuk itu sektor jasa mengatur strategi pemasaran untuk menarik konsumen sehingga memutuskan untuk memilih dan membelinya, jika tidak konsumen/pelanggan akan beralih. Untuk menarik konsumen atau pelanggan, maka harus diciptakan sistem strategi pemasaran yang tepat sesuai degan kondisi yang dihadapi, berdasarkan kebutuhan dan lingkungan.

Keputusan pembelian merupakan proses penyelesaian masalah, mencari informasi terkait produk dan merek tertentu untuk mengevaluasi seberapa baik masing-masing alternative tersebut bisa menyelesaikan masalah, penilaian sumber-sumber seleksi terhadap alternative pembeliaan, keputusan pembeliaan dan prilaku setelah terjadinya pembeliaan (Tjiptono, 2016). Oleh karena itu, strategi yang tepat harus dirancang dan dilaksanakan sehingga bisa memenuhi kebutuhan konsumen dalam mencapai tujuan dari perusahaan serta dapat mempertahankan penjualan. Strategi ini dimulai dari produk, harga, dan promosi yang sedang ditawarkan. Salah satu yang paling andil berperan untuk membentuk, mengembangkan, mengarahkan pertukaran yang saling menguntungkan antara konsumen dan produsen sehingga terjalin kerja sama dalam jangka panjang adalah seorang marketing. Salah satu strategi di bidang bisnis, marketing merupakan tindakan penyesuaian suatu organisasi yang berorientasi pasar, baik dalam lingkungan internal dan lingkungan eksternal yang terus berkembang. Dengan adanya berbagai strategi diharapkan nasabah akan memperoleh kepuasaan dalam menggunakan produk pembiayaan dari Bank.

BPRS Puduarta Insani merupakan salah satu Bank Pembiayaan Rakyat Syariah yang memiliki produk dan menjalankan layanan diantaranya, tabungan, deposito serta produk pembiayaan syariah berupa, murabahah, multi jasa, ijarah dan qard. BPRS Puduarta Insani termasuk bank yang gencar dan cukup sehat dalam menarik nasabah untuk melakukan transaksi pembiayaan. Berikut data dari tahun ke tahun bisa kita lihat banyaknya jumlah nasabah yang melakukan pembiayaan pada table 1 berikut :

Tabel 1 Data Produk Pembiayaan Tahun 2016 - 2018 di PT Bank Pembiayaan Rakyat Syariah Puduarta Insani Medan

\begin{tabular}{lccc}
\hline \multicolumn{1}{c}{ Bulan } & $2018(\mathrm{Rp})$ & $2019(\mathrm{Rp})$ & $2020(\mathrm{Rp})$ \\
\hline Januari & 42.436 .655 .745 & 37.462 .340 .954 & 29.705 .086 .020 \\
\hline Februari & 42.257 .926 .602 & 38.080 .342 .162 & 29.487 .890 .446 \\
\hline Maret & 40.897 .433 .932 & 38.203 .795 .749 & 29.876 .651 .989 \\
\hline April & 39.671 .219 .095 & 38.427 .686 .668 & 28.301 .632 .611 \\
\hline
\end{tabular}




\begin{tabular}{llll}
\hline Mei & 39.278 .399 .832 & 38.815 .219 .032 & 28.243 .522 .021 \\
\hline Juni & 38.957 .216 .411 & 37.946 .042 .442 \\
\hline Juli & 37.567 .950 .424 & 37.790 .317 .627 \\
\hline Agustus & 35.736 .359 .727 & 37.416 .015 .407 \\
\hline September & 35.423 .796 .384 & 36.818 .076 .086 \\
\hline Oktober & 33.993 .199 .164 & 36.444 .987 .484 \\
\hline November & 33.339 .520 .088 & 35.020 .924 .378 \\
\hline Desember & 36.922 .080 .109 & 34.892 .031 .584 \\
\hline \multicolumn{4}{c}{ Sumber : PT. Bank Pembiayaan Rakyat Syariah Puduarta Insani 2020 }
\end{tabular}

Dilihat dari Tabel 1 di atas data pembiayaan dari tahun 2018 sampai dengan tahun 2020 pada BPRS Puduarta Insani Medan mengalami penurunan hingga tahun 2020 di mana pada 2018 pembiayaan yang tertinggi terjadi dibulan Januari sebesar 42.436.655.745, namun di bulan berikutnya di tahun 2018 terus mengalami penurunan. Begitu juga ditahun 2019 produk pembiayaan cendrung mengalami penurunan. Pembiayaan yang tertinggi terjadi dibulan Mei sebesar 42.815.219.032 dan yang terendah terjadi di bulan desember sebesar 34.892.031.584. dan ditahun 2020 pembiayaan terendah pada bulan Mei sebesar 28.243.522.021 sedangkan pada bulan maret pembiayaan tetinggi yaitu pada bulan maret sebesar 29.876.651.989. dengan menurunya jumlah nasabah yang melakukan pembiayaan di BPRS Puduarta Insani Medan maka peneliti tertarik untuk mengangkat pembiayaan di PBPRS Puduarta Insani sebagai objek dalam sebuah penelitian.

Jika pembiayaan BPRS di berikan kepada pelaku UMKM yang bermasalah maka akan berdampak kepada penurunan pembiayaan, sehingga di prediksikan upaya guna menstabilkan dan mendorong pertumbuhan ekonomi di Indonesia akan menjadi terhambat. Semua lembaga keuangan mempunyai jasa yang akan di tawarkan kepada masyarakat agar minat memakai jasanya karena semakin banyak masyarakat memakai jasa suatu lembaga keuangan secara tidak langsung masyarakat pun ikut berperan dalam pertumbuhan ekonomi. Sama dengan BPRS yang selalu menawarkan jasa dengan sistem pembiayaan syariah. Salah satu upaya untuk meningkatkan produk pembiayaan oleh nasabah adalah melalui bauran pemasaran. produk, price dan promotion berpengaruh signifikan terhadap keputusan pembeliaan. (William Putra Imbar, Silv 2014) bauran pemasaran terdapat pengaruh positif dan signifikan secara model regresi liner berganda terhadap layanan minat nasabah. (Muasyaroh, 2014)

Dari temuan tersebut peneliti tertarik untuk melakukan peneliti yang berkaitan dengan produk pembiayaan dengan judul Pengaruah Strategi Product, Price, Promotion Terhadap Keputusan Nasabah melakukan Pembiayaan pada PT BPRS Puduarta Insani Medan.

\section{METODE}

Penelitian ini merupakan penelitian asosiatif dengan pendekatan kuantitatif yang bertujuan untuk menganalisa hubungan sebab-akibat dengan cara mengamati akibat yang terjadi dan kemungkinan faktor (sebab) yang menimbulkan akibat tersebut serta menampilkan informasi yang diperoleh dalam bentuk numerik. Penelitian ini di lakukan di PT Bank Pembiayaan Rakyat Syariah Puduarta Insani di J1 Pekan Raya No.13A Tembung Medan. Waktu penelitian dilaksanakan pada bulan desember 2021. Variabel bebas penelitian ini adalah produk, price dan promosi, sedangkan variabel terikatnya 
adalah keputusan nasabah. Penelitiain ini melibatkan nasabah yang melakukan pembiayaan di PT Bank Pembiayaan Rakyat Syariah Puduarta Insani sebagai populasi penelitian dengan total terdapat 800 nasabah. Oleh karena itu, teknik sampling probabilitas digunakan pada proses penentuan sampel. Hasilnya sebanyak 89 kuesioner di berikan kepada nasabah yang telah melakukan produk pembiayaan. Sehingga jumlah tersebut dapat memenuhi syarat yang telah ditetapkan. Metode dan prosedur pengumpulan data dalam penelitian ini menggunakan wawancara, kuesioner dan observasi. Pengujian Instrumen Penelitian ini dilakukan dengan uji validitas dan realibilitas, uji asumsi klasik, uji normalitas, uji linearitas, uji multikolinearitas, uji heterokedastisitas, uji $\mathrm{T}$ dan uji $\mathrm{F}$. serta menggunakan analisis regresi linear berganda untuk mengetahui berapa besar pengaruh variable bebas produk, price dan promosi terhadap variable terikat keputusan pembelian. Dan koefisiensi determinasi $\left(\mathrm{R}^{2}\right)$ digunakan untuk mengetahui kemampuan variable independen dalam menjelaskan variable dependen.

\section{HASIL DAN PEMBAHASAN}

Uji Validitas

Seluruh item pertanyaan pada semua variabel penelitian dengan menggunakan bantuan software Statistical Product and Service Solution (SPSS) version 21, dinyatakan sebanyak 3 butir angket product dinyatakan valid, kemudian sebanyak 2 butir angket price dinyatakan valid dan 3 butir angket promotion dinyyatakan valid. Beriku uji validitas dari hasil pengolahan data.

Tabel 2 Uji Validitas Product, Price, Promotion

\begin{tabular}{ccccc}
\hline & No. Item & $\boldsymbol{r}_{\text {hitung }}$ & $\boldsymbol{r}_{\text {tabel }}$ & Keterangan \\
\hline \multirow{2}{*}{ Product } & 1. & 0,659 & 0,361 & Valid \\
\cline { 2 - 5 } & 2. & 0,757 & 0,361 & Valid \\
\cline { 2 - 5 } Price & 3. & 0,709 & 0,361 & Valid \\
\cline { 2 - 5 } & 1. & 0,807 & 0,361 & Valid \\
\hline \multirow{2}{*}{ Promotion } & 2. & 0,752 & 0,361 & Valid \\
\cline { 2 - 5 } & 1. & 0,719 & 0,361 & Valid \\
\cline { 2 - 5 } & 2. & 0,732 & 0,361 & Valid \\
\hline & 3. & 0,629 & 0,361 & Valid \\
\hline & & & Sumber : Pengolahan Data Primer, 2019
\end{tabular}

Uji Reliabilitas

Diketahui hasil uji reliabilitas nilai cronbach's alpha sebesar 0,606 pada variabel product sehingga nilai tersebut lebih besar dari $r_{\text {tabel }}$ yaitu 0,60. Kemudian nilai cronbach's alpha sebesar 0,657 pada variabel price sehingga nilai tersebut lebih besar dari $r_{\text {tabel }}$ yaitu 0,60 , dan nilai cronbach's alpha sebesar 0,635 pada variabel promotion sehingga nilai tersebut.

\section{Karakteristik Responden}

Berikut deskripsi karakteristik responden untuk penelitian ini meliputi jenis kelamin, usia dan pekerjaan. Responden pada penelitian ini sebanyak 89 orang yaitu, konsumen yang pernah membeli produk pembiayaan. diketahui bahwa responden 
berdasarkan jenis kelamin Laki-laki sebanyak 67 orang dengan persentase sebesar $75,28 \%$ sedangkan yang berjenis kelamin Perempuan sebanyak 22 orang dengan persentase sebesar $24.72 \%$. Sehingga dapat disimpulkan mayoritas pelanggan produk pembiayaan adalah laki-laki. Kemudian karakteristik responden berdasarkan usia diketahui bahwa mayoritas pelanggan adalah responden dengan usia 25 - 35 tahun yaitu sebanyak 43 orang dengan persentase sebesar 48,31\%. Kemudian karakteristik responden berdasarkan pekerjaan diketahui bahwa mayoritas pelanggan adalah wiraswata sebanyak 38 orang dengan persentase sebesar $42.70 \%$. Berikut hasil pengolahan data

Tabel 3 Karakteristik Responden Berdasarkan Jenis Kelamin

\begin{tabular}{|c|c|c|c|}
\hline \multirow[t]{2}{*}{ Karakteristik } & \multirow{2}{*}{ Kategori } & \multicolumn{2}{|c|}{ Jumlah } \\
\hline & & Nominal & $\%$ \\
\hline \multirow[t]{2}{*}{ Jenis Kelamin } & Perempuan & 22 & 24,72 \\
\hline & Laki-laki & 67 & 75,28 \\
\hline \multirow[t]{4}{*}{ Umur } & $<25$ tahun & 7 & 7,87 \\
\hline & $25-35$ tahun & 43 & 48,31 \\
\hline & $36-45$ tahun & 22 & 24,72 \\
\hline & $>45$ tahun & 17 & 19,10 \\
\hline \multirow[t]{4}{*}{ Pekerjaan } & Pegawai Swasta & 25 & 28,09 \\
\hline & Wiraswasta & 38 & 42,70 \\
\hline & Ibu Rumah Tangga & 20 & 22,47 \\
\hline & Dan lain - lain & 6 & 6,74 \\
\hline
\end{tabular}

\section{Uji Normalitas}

Uji Normalitas bertujuan untuk mengetahui apakah dalam model regresi nilai residual berdistribusi secara normal atau tidak. Model regresi yang baik adalah model yang memiliki nilai residual yang memenuhi asumsi normalitas yaitu nilai $\operatorname{Sig} .>\alpha(0,05)$. diketahui nilai Asymp.Sig (2-tailed) sebesar 0,288. Nilai tersebut lebih besar dari taraf signifikansi $\alpha=0,05$. Maka dapat disimpulkan bahwa nilai residual berdistribusi normal. Berikut hasil pengolahan data.

Tabel 4. Uji Normalitas

One-Sample Kolmogorov-Smirnov Test

\begin{tabular}{|ll|r|}
\hline & & \multicolumn{2}{|c|}{ Unstandardized Residual } \\
\hline Normal Parameters ${ }^{\mathrm{a}, \mathrm{b}}$ & Mean & 89 \\
& Std. Deviation & .0000000 \\
& Absolute & 11.60840583 \\
& .104 \\
Most Extreme Differences & Positive & .104 \\
& Negative & -.066 \\
Kolmogorov-Smirnov Z & & .984 \\
Asymp. Sig. (2-tailed) & & .288 \\
\hline
\end{tabular}

Sumber : Pengolahan Data Primer menggunakan SPSS

\section{Uji Linearitas}

Pengujian linearitas pada penelitian ini bertujuan untuk mengetahui apakah 
Product,price, Promotion, memiliki hubungan yang linear terhadap Keputusan Pembelian dengan asumsi nilai Sig. pada Deviation from Linearity lebih besar dari taraf signifikansi $\alpha=0,05$. Hasil uji linearitas dapat dilihat pada Tabel 5 di bawah ini.

Tabel 5 Uji Linearitas terhadap Keputusan Nasabah ANOVA Table

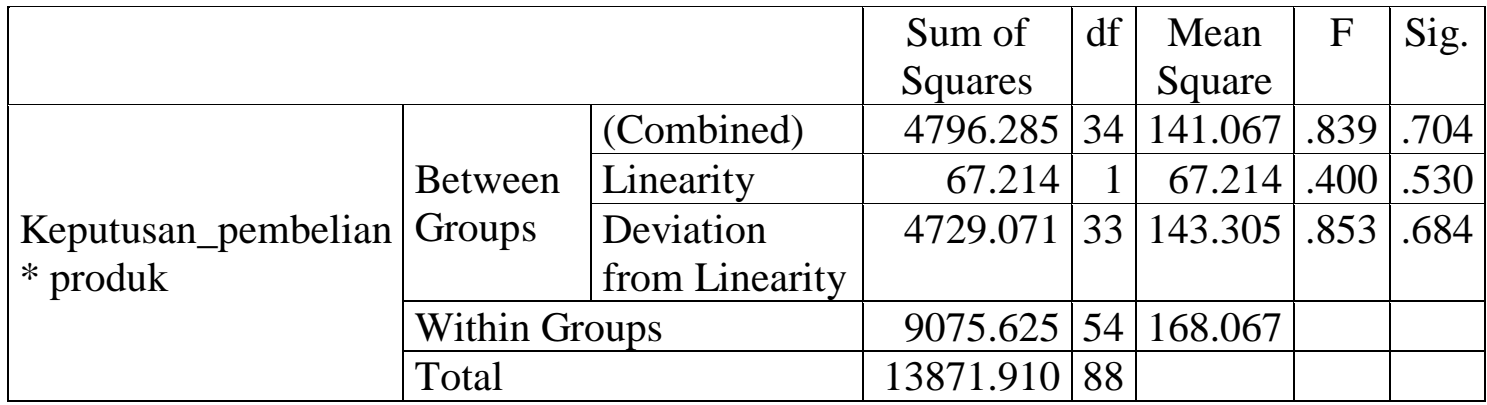

\section{Uji Multikolinearitas}

Sumber : Pengolahan Data Primer menggunakan SPSS

Uji ini bertujuan untuk mengetahui apakah dalam model regresi ditemukan adanya korelasi antar variabel bebas. Untuk menguji multikoliearitas digunakan Variance Inflation Factor (VIF). diketahui tolerance $>0,1$ dan VIF $<10$, Dengan demikian dapat disimpulkan bahwa persamaan model regresi tidak mengandung masalah multi kolinearitas. Pada hasil analisis diperoleh nilai tolerance untuk produk, price dan promosi sebesar 0,527; 0,455; dan 0,774, sedangkan nilai VIF sebesar 1,896; 2,199; dan 1,292. Berdasarkan hasil tersebut korelasi antar variabel bebas tidak saling mempengaruhi.

\section{Uji Heterokedasitas}

dapat terlihat bahwa tidak ada pola yang jelas serta titik-titik menyebar diatas dan dibawah angka 0 pada sumbu $\mathrm{Y}$, maka berdasarkan metode grafik tidak terjadi heteroskedastisitas pada model regresi layak dipakai untuk memprediksi keputusan pembeliaan berdasarkan masukan variabel product, price, dan promotion.

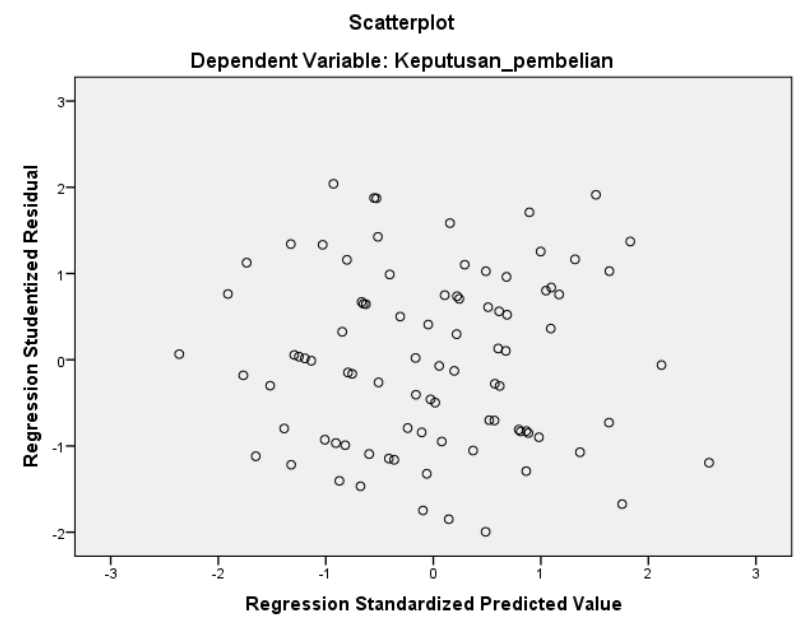

\section{Analisis Regresi Berganda}

Gambar 1. Scatterplot Heteroskedastisitas

Analisis regresi linear berganda digunakan untuk mengetahui berapa besar pengaruh variabel bebas Product, Price, Promotion terhadap variabel terikat Keputusan 
nasabah. Data di olah dengan statistic untuk mengetahui analisis dan pengujian hipotesis dengan menggunakan alat bantu progam SPSS. Adapun Hasil analisis regresi berganda terlihat pada Tabel 6 .

Tabel 6 Analisis Regresi Berganda

\begin{tabular}{|c|c|c|c|c|c|c|}
\hline \multicolumn{7}{|c|}{ Coefficients $^{\mathbf{a}}$} \\
\hline \multirow{2}{*}{\multicolumn{2}{|c|}{ Model }} & \multicolumn{2}{|c|}{$\begin{array}{l}\text { Unstandardized } \\
\text { Coefficients }\end{array}$} & \multirow{2}{*}{$\begin{array}{c}\text { Standardized } \\
\text { Coefficients }\end{array}$} & \multirow[t]{2}{*}{$\mathrm{t}$} & \multirow[t]{2}{*}{ Sig. } \\
\hline & & B & Std. Error & & & \\
\hline \multirow{4}{*}{1} & (Constant) & 24.835 & 24.081 & & 1.031 & .305 \\
\hline & Produk & .405 & .175 & .328 & 2.319 & .023 \\
\hline & Price & .375 & .174 & .328 & 2.156 & .034 \\
\hline & Promosi & .228 & .105 & .255 & 2.186 & .032 \\
\hline
\end{tabular}

a. Dependent Variable: Keputusan_nasabah

Berdasarkan hasil regresi linear berganda di atas, Produk, Harga dan Promosi berpengaruh positif terhadap Keputusan Pembelian. Adapun nilai konstanta (a) sebesar 24,835 artinya jika Produk, Harga,dan Promosi sebesar nol, maka Keputusan Pembelian bernilai konstan sebesar 24,835. Nilai koefisien regresi Produk ( $b_{1}$ ) sebesar 0,405. Artinya, jika Produk mengalami kenaikan, maka Keputusan Pembelian akan mengalami peningkatan sebesar 0,405 dengan syarat variabel independen lainnya bernilai tetap. Nilai koefisien regresi Harga $\left(b_{2}\right)$ adalah sebesar 0,375. Artinya, jika Harga mengalami kenaikan, maka Keputusan Pembelian akan mengalami peningkatan sebesar 0,375 dengan syarat variabel independen lainnya bernilai tetap. Nilai koefisien regresi Promosi $\left(b_{3}\right)$ adalah sebesar 0,228. Artinya, jika Kualitas Promosi mengalami kenaikan, maka Keputusan Pembelian akan mengalami peningkatan sebesar 0,228 dengan syarat variabel independen lainnya bernilai tetap.

\section{Koefisien Determinasi $\left(\mathbf{R}^{2}\right)$}

Pengujian koefisien determinasi dilakukan untuk mengetahui seberapa besar sumbangan atau kontribusi variabel independen Promosi, Persepsi Harga dan Kualitas Produk terhadap Keputusan Pembelian secara bersamaan. Hasil uji koefisien determinasi dapat dilihat pada Tabel 7 sebagai berikut.

Tabel 7 Uji Koefisien Determinasi

Model Summary

\begin{tabular}{llrrr}
\hline Model & R & R Square & Adjusted R Square & Std. Error of the Estimate \\
\hline 1 & $.381^{\mathrm{a}}$ & .145 & .071 & 12.09961 \\
\hline
\end{tabular}

a. Predictors: (Constant) price, promosi, produk

Sumber : Pengolahan Data Primer menggunakan SPSS

Dari tabel di atas, diperoleh nilai koefisien determinasi ( $R$ square) sebesar 0,145 yang artinya adalah sebesar 14,5\% variabel Product, Price dan Promotion memberikan pengaruh terhadap Keputusan Pembelian, dan sisanya yaitu sebesar 85,5\% dijelaskan oleh variabel lain yang tidak dikaji dalam penelitian ini.

\section{Pengujian Hipotesis Serempak (Uji F)}


Untuk mengetahui pengaruh Product, Price, Promotion, terhadap Keputusan Pembelian produk pembiayaan pada nasabah produk pembiayaan secara serempak, maka dilakukan uji hipotesis secara serempak (Uji F). Hasil pengujian hipotesis secara serempak (Uji F) dapat dilihat pada Tabel 8 di bawah ini.

Tabel 8 Uji Hipotesis secara Serempak (Uji F)

\begin{tabular}{lllllll}
\multicolumn{6}{c}{ ANOVA $^{\mathbf{a}}$} \\
\hline Model & $\begin{array}{l}\text { Sum of } \\
\text { Squares }\end{array}$ & Df & Mean Square F & Sig. \\
\hline \multirow{3}{*}{1} & Regression & 2013.463 & 7 & 287.638 & 1.965 & $.049^{\mathrm{b}}$ \\
\cline { 2 - 7 } & Residual & 11858.448 & 81 & 146.401 & & \\
\cline { 2 - 6 } & Total & 13871.910 & 88 & & & \\
\hline
\end{tabular}

a. Dependent Variable: Keputusan_nasabah

b. Predictors: (Constant), price, promosi , produk

Sumber : Pengolahan Data Primer menggunakan SPSS

Dari hasil di atas, diketahui nilai $F_{\text {hitung }}$ adalah sebesar 1,965 dengan nilai signifikansi adalah 0,049. Sedangkan nilai $F_{\text {tabel }}$ pada derajat kebebasan df (N1) sebesar 3,92. Dapat disimpulkan $F_{\text {hitung }}>F_{\text {tabel }}(1,965>3,92)$ dan nilai signifikansi lebih kecil dari taraf signifikan $\alpha=0,05(0,049<0,05)$. Dengan demikian, maka hipotesis ketiga diterima yang menyatakan bahwa Product, Price, Promotion berpengaruh positif dan signifikan secara serempak terhadap Keputusan nasabah melakukan pembiayaan.

\section{Pengujian Hipotesis secara Parsial (Uji T)}

Uji hipotesis secara parsial (Uji t) dilakukan untuk mengetahui pengaruh secara parsial variabel independen terhadap variabel dependen. Pengujian ini dilakukan untuk menguji hipotesis pertama, kedua dan ketiga. Hasil pengujian hipotesis secara parsial (Uji t) dapat dilihat pada Tabel 9 .

Tabel 9 Uji Hipotesis secara Parsial (Uji t)

\section{Coefficients $^{\mathrm{a}}$}

\begin{tabular}{|c|c|c|c|c|c|c|}
\hline & \multirow[t]{2}{*}{ Model } & \multicolumn{2}{|c|}{$\begin{array}{c}\text { Unstandardized } \\
\text { Coefficients }\end{array}$} & \multirow{2}{*}{$\begin{array}{c}\begin{array}{c}\text { Standardized } \\
\text { Coefficients }\end{array} \\
\text { Beta }\end{array}$} & \multirow[t]{2}{*}{$\mathrm{T}$} & \multirow[t]{2}{*}{ Sig. } \\
\hline & & $\mathrm{B}$ & Std. Error & & & \\
\hline \multirow{4}{*}{1} & (Constant) & 24.835 & 24.081 & & 1.031 & .305 \\
\hline & Produk & .405 & .175 & .328 & 2.319 & .023 \\
\hline & Price & .375 & .174 & .328 & 2.156 & .034 \\
\hline & Promosi & .228 & .105 & .255 & 2.186 & .032 \\
\hline
\end{tabular}

a. Dependent Variable: Keputusan_nasabah

Sumber: Pengolahan Data Primer menggunakan SPSS

Berdasarkan hasil yang diperoleh di atas, diketahui nilai koefisien Produk adalah sebesar 0,405 dengan nilai signifikansi sebesar 0,023, Hasil tersebut menunjukkan bahwa hipotesis pertama diterima, yang menyatakan bahwa Produk berpengaruh positif dan signifikan terhadap Keputusan nasabah melakukan pembiayaan.

Berdasarkan hasil analisa data. Diketahui bahwa variabel product, price, dan 
promotion memiliki pengaruh positif dan signifikan terhadap keptusan pembelian product pembiayaan. Sedangkan vavriabel yang memiliki pengaruh terbesar terhadap keputusan pembelian product pembiayaan, yaitu variabel product. Hal ini dapat dari hasil olah data dimana nilai uji t hitung dan koefisien determinasi dari variabel ini memiliki nilai paling besar dari variabel lainnya. Kemudian disusul variabel promotion dan price. Variabel product berkaitan dengan jasa yang ditawarkan kepada nasabah, sehingga dapat disimpulkan bahwa variabel bebas Produk (X1) secara parsial berpengaruh positif dan signifikan terhadap Keputusan Pembelian Produk Pembiayaan. Hal ini dapat diketahui dari jawaban responden dengan pernyataan mengenai produk yang memperoleh nilai 2,32 dikategorikan sangat baik. Karena Produk yang ditawarkan sesuai prinsip syariah yaitu berdasarkan hukum islam antara bank dan pihak lain untuk penyimpanan dana atau pembiayaan kegiatan usaha sesuai dengan prinsip bagi hasil. Selain proses yang mudah dipahami dalam perjanjian akad antara Bank dan calon nasabah, aman, menguntungkan dan layanan produk-produk pada PT BPRS Puduarta Insani juga berlaku universal yang artinya dapat diakses oleh siapa saja.

\section{KESIMPULAN}

Berdasarkan hasil penelitian diketahui bahwa product, price dan promotion berpengaruh positif dan signifikan terhadap keputusan pembelian produk pembiayan. Sehingga dapat disimpulkan bahwa product, price dan promotion dapat meningkatkan produk pembiayan, maka perlunya inovasi baru sehingga bisa lebih menarik konsumen dalam melakukan pembiayan. Banyaknya jumlah perbankan yang terdapat di Indonesia khususnya daerah Medan menyebabkan tingginya tingkat persaingan antar Bank dalam menarik perhatian konsumen untuk menjadi nasabah produk pembiayaan, sehingga perlu ditingkatkannya usaha PT BPRS Puduarta Insani dalam mensosialisasikan produknya dikalangan masyarakat umum, tidak hanya di lingkungan daerah UINSU dan Tembung. Promosi yang dapat dilakukan diantaranya dengan melakukan kegiatan masyarakat, pemberian hadiah atau souvenir dan brosur bagi konsumen atau calon nasabah merupakan salah satu cara yang dapat menimbulkan kesan positif. Selain meningkatkan promosi, PT BPRS Puduarta Insani harus meningkatkan pelayanan terhadap nasabah dan menjalin hubungan baik hingga tercipta presepsi yang baik kepada perusahaan. Jika presepsi nasabah sudah baik maka nasabah akan mempromosikan secara word of mouth kepada orang lain. Penelitian ini dapat dilaksanakan dengan baik berkat bantuan dari berbagai pihak, untuk itu peneliti mengucapkan terima kasih kepada Manajer PT Bank Pembiayaan Rakyat Syariah Puduarta Insani serta jajaran Staf, dan para nasabah yang telah membantu saya dalam mendapatkan informasi dan telah memberikan kerjasama yang baik dalam penelitian yang saya lakukan.

\section{REFERENSI}

Arsip Data Produk Pembiayaan di PT Bank Pembiayaan Rakyat Syariah Puduarta Insani Medan.

Anggoro Dwi Kurniawan, S. R. T. A. (2012). Analisis Pengaruh Produk, Promosi, Harga dan Tempat Terhadap Keputusan Pembelian (Studi Pada Kedai Amarta Semarang). Of Manajemen, 1(1), 282-289.

Arifin, Z. (2010). Memahami Bank Syariah. Alfabet.

Bayu Yulianto, K. (2013). Pengaruah Produk, Harga, Promosi, Layanan Terhadap Keputusan Konsumen Membeli Sepeda Motor Kawasaki. Ilmu Dan Riset 
Manajemen, 1(1).

Firliyanti, Kaluku, Silvya L. Mandey, Djurwati, S. (2018). Analisis Bauran Promosi Terhadap Keputusan Nasabah Menggunakan Produk Unggulan pada Bank Syariah Mandiri Cabang Manado. EMBA, 6(2), 888-897.

Facrul Rizal, Muhammad Adam, M. I. (2017). Pengaruh Harga Desain dan Lokasi

Terhadap Keputusan Pembelian Serta Dampaknya pada Kepuasan Paska

Pembeliaan Perumahan di Kota Banda Aceh. Manajemen Inovasi, 8(3), 76-87.

Faedah, N. (2016). Pengaruh Produk dan Harga terhadap Keputusan Pembelian Pakaian

Lea pada Showroom Lea di Samarinda. Ilmu Administrasi Bisnis, 4(1), 237-249.

Kotler, P. (2016). Principles of Marketing. Pearson Education Limited.

Muasyaroh, H. H. (2014). Pengaruh Bauran Pemasaran Terhadap Minat Nasabah Menggunakan E-Banking PT Bank Syariah Yogyakarta.

SPSS, A. M. dengan P. (2011). Imam Ghozali. Undip.

Tjiptono, F. (2016). Strategi Pemasaran (Edisi 3). Andi.

William Putra Imbar, Silvya L. Manday, A. S. S. (2014). Bauran Pemasaran Jasa Terhadap Keputusan Pembelian Motor Yamaha Pda PT Hasjrat Abadi Manado. Jurnal EMBA, 2(3), 526-538.

Wati, T. D. (2014). Analisis Pengaruh Faktor-Faktor Bauran Pemasaran Jasa Terhadap Keputusan Siswa Memilih Sekolah SMK di Kota Palangka Raya. Sains Manajemen, 3(2), 149-169.

Zulaicha, Santri, R. I. (2016). Pengaruh Produk dan Harga Terhadap Keputusan Pembelian Konsumen di Morning Bakery Batam. Inovasi Dan Bisnis, 4(2).125-136 